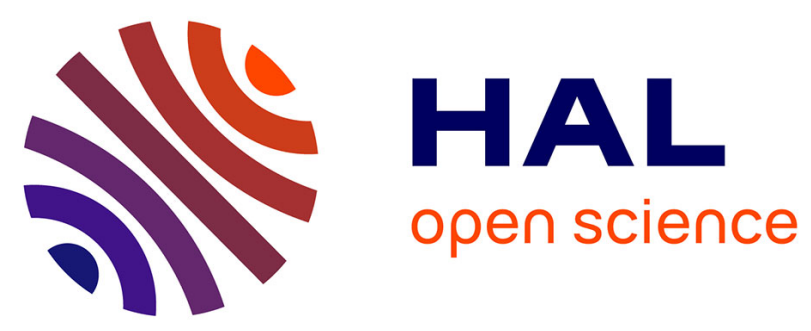

\title{
Dissolution precipitation creep as a process for the strain localisation in gabbro
}

Amicia Lee, Holger Stunitz, Matheus Ariel Battisti, Jiri Konopasek

\section{To cite this version:}

Amicia Lee, Holger Stunitz, Matheus Ariel Battisti, Jiri Konopasek. Dissolution precipitation creep as a process for the strain localisation in gabbro. EGU General Assembly 2020, May 2020, Online, France. 10.5194/egusphere-egu2020-13523 . hal-03554410

\author{
HAL Id: hal-03554410 \\ https://hal.science/hal-03554410
}

Submitted on 4 Feb 2022

HAL is a multi-disciplinary open access archive for the deposit and dissemination of scientific research documents, whether they are published or not. The documents may come from teaching and research institutions in France or abroad, or from public or private research centers.
L'archive ouverte pluridisciplinaire HAL, est destinée au dépôt et à la diffusion de documents scientifiques de niveau recherche, publiés ou non, émanant des établissements d'enseignement et de recherche français ou étrangers, des laboratoires publics ou privés. 
EGU2020-13523

https://doi.org/10.5194/egusphere-egu2020-13523

EGU General Assembly 2020

(c) Author(s) 2022. This work is distributed under

the Creative Commons Attribution 4.0 License.

\title{
Dissolution precipitation creep as a process for the strain localisation in gabbro
}

\author{
Amicia Lee ${ }^{1}$, Holger Stunitz ${ }^{1,2}$, Matheus Ariel Battisti ${ }^{3}$, and Jiri Konopasek ${ }^{1}$ \\ ${ }^{1}$ University of Tromsø, Department of Geosciences, Tromsø, Norway (amicia.lee@uit.no) \\ ${ }^{2}$ Université d'Orléans, ISTO, Orléans, France \\ ${ }^{3}$ Universidade Federal do Rio Grande do Sul, Institute of Geosciences, Porto Alegre, Brazil
}

Strain localisation and fabric development in the lower crust is controlled by the active deformation mechanisms. Understanding the driving forces of such deformation aids in quantifying the stresses and rates of the deformation processes. Here we show that diffusion creep plays a major role in deformation of gabbro lenses at upper amphibolite facies conditions. The Kågen gabbro in the North Norwegian Caledonides intruded the Vaddas Nappe at $439 \mathrm{Ma}$ at pressures of 7-9 kbar, temperatures of $650-900^{\circ} \mathrm{C}$ (depths of $\square 26-34 \mathrm{~km}$ ). The Kågen gabbro on south Arnøya is made up of undeformed gabbro lenses with sheared margins wrapping around them. This contribution analyses the evolution of the microstructures and fabric of the low strain gabbro to high strain margins. Microstructural and textural data indicate that preferential crystal growth of amphibole grains in the extension direction has produced the deformation microstructure and the CPO. Dissolution precipitation creep is inferred to be the dominant deformation mechanism, where dissolution of the gabbro took place in reacting phases of clinopyroxene and plagioclase, and precipitation took place in the form of new minerals: amphibole, garnet and zoisite. Synchronous deformation and mineral reactions of clinopyroxene suggests mafic rocks can become mechanically weak during the general transformation weakening process, i.e. the interaction of mineral reaction and deformation by diffusion creep. Deformation and metamorphic reaction were both important transformation processes during diffusion creep deformation of the margins of the gabbro lenses. The weakening is directly connected to a transformation process that facilitates diffusion creep deformation of strong minerals (pyroxene, garnet, zoisite) at far lower stresses than dislocation creep. Initially strong lithologies can become weak, provided that reactions can proceed during deformation, the transformation process itself is an important weakening mechanism in mafic (and other) rocks, facilitating deformation at low differential stresses. 